\title{
Effective Factors Influencing the Intention to Use Citizens Complaint Handling System
}

\author{
Nur Shabrina Meutia*, Apol Pribadi Subriadi \\ Dept of Information System, Faculty of Intelligent Electrical and Informatics Technology, Institut Teknologi Sepuluh \\ Nopember \\ Jalan Raya Sukolilo, Surabaya 60117, INDONESIA \\ Email: shabrinameutia@gmail.com, apolpribadi@gmail.com
}

*Corresponding Author

\begin{abstract}
The citizen's complaint handling system aims to make citizens easily file a complaint against the condition and development of the city so that it can be followed up immediately, but the implementation of this Smart City program is less than optimal. The real condition shows that there are still many citizens who have not used this application. This study aims to evaluate what factors influence the citizens intention to use the complaint handling application. The methodology used in this study is a qualitative method with a phenomenological approach. This study conducted in-depth interviews with six research informants, then the results of the interviews were tested and analyzed, and the interview data was encoded. The results of this study found factors that influence the intention to use complaint handling applications. These factors are citizen awareness, social influence, perceived usefulness, and trust. The expected result is a new model that can be implemented to improve the use of complaint handling applications and similar e-government services.
\end{abstract}

Key words: Complaint handling, Citizen awareness, Social influence, Perceived usefulness, Trust, MataramKu Lapor

\section{INTRODUCTION}

During recent years, the development of technology information and communication has brought impact to daily life. The development of information and the rapidly growing digital world have affected all aspects of life, including the public service sector. The government has made serious efforts in solving the urban problems creatively through the utilization of ICT, called Smart City. One of the smart city programs is citizens complaint handling system. This system is intended so that the citizen can easily submit complaints about the conditions and regional development so that they can be immediately followed up. For example, these complaints are related to cleanliness, health, roads, bridges, drainage, public road lighting, and other things that are troubling to residents. This research takes a sample of one of the complaint handling applications in Indonesia specifically in Mataram city, named Mataramku Lapor, created by the Mataram city government. The government has conducted socialization to the citizen regarding the use of the Mataramku Lapor. But in fact, Mataramku Lapor are not widely known by the citizen. This is known from the small number of users of Mataramku Lapor. This system is expected to help the citizen to files a complaint easily without having to do it manually through face-to-face services. Mataramku Lapor is also expected to increase the productivity of government in handling and following up on a complaint submitted by the citizen. But until now there has been no evidence that Mataramku Lapor has been used effectively. It is evident from the number of accounts that have downloaded the Mataramku Lapor application, only about 100 people or just $0.02 \%$ of the citizens of Mataram [1]. This fact raises the big question "Is this system effective in implementing it?".

Based on the results of the survey that has been conducted, it is found the main factors that cause the low use of Mataramku Lapor. Of the 52 citizens of Mataram city who filled out the online survey, only 17 participants already knew about the application. This indicates that public awareness of Mataramku Lapor is still low. Whereas awareness of the existence of e-government services is positively related to the use of e-government services [2]. Meanwhile, from participants who already knew about Mataramku Lapor, the majority stated that they used the application based on recommendations from friends or relatives. This indicates that social influence presents an important role in influencing prospective new users. According to Venkatesh [3], social influence is defined as the extent to which an individual who is considered important by others believes that they must use a new system. In addition, most participants stated that they used the application because they thought Mataramku Lapor could help solve their problems. Perceived usefulness has the perception that using the system, work can be finished quickly, helps save time and costs, and can increase work productivity [4]. Again, the participants who had used the application stated that they used the application because they believe in government. This initiate that Trust is a crucial factor at the initial stage of the introduction or adoption of online-based technology because Trust is a factor that influences individuals to engage in online transactions and is an integral part of the system [5]. Lack of a Trust factor can prevent individuals from engaging in online transactions.

Based on the description above, this study focuses on researching and analyzing what factors that influence the effectiveness of using e-government services in the Smart 
City program, especially the Mataramku Lapor. This study uses a qualitative method with a phenomenological approach, which is an approach that studies the subjective experiences and perspectives of others from a phenomenon that has occurred or is felt. In this study, individual perspectives on the domains of this study will be explored, namely awareness, social influence, perceived usefulness, and trust in influencing people's interest in downloading or using the complaint handling applications. This study provides a theoretical contribution to the effectiveness model and provides a new strategy for implementing the Mataramku Lapor and a similar complaint handling system in Indonesia so that the citizen desire to use the application increases.

\section{LITERATURE REVIEW}

Several studies have been carried out related to the citizens intentions to use the e-government's services. Akbar [6] conducted a research about the effectiveness of "LAPOR!" in Bandung city, Indonesia. Complaint handling system named LAPOR! is one of smart city program created by Indonesian central government which is the first service system for delivering citizen aspirations and complaints online based on the easy, integrated, and complete principle for monitoring development programs and public services. The research stated that the application of LAPOR! has not been used thoroughly in the city of Bandung. This case lead by several factors including lack of socialization, lack of knowledge of technology and the benefits of LAPOR! applications, as well as supporting devices that the community has not partially owned, making it difficult for people to adopt the application. This proves that not everyone can accept the technology that has been provided. They developed a model from the modified UTAUT. Their study included 400 participants. Empirical results revealed that performance expectancy, effort expectancy, social influence, and facilitating conditions have an important and positive influence on the LAPOR's behavioral intention. On the other hand, effort expectancy was found to have the highest value on behavioral intention.

In another similar study, Venkatesh [7] examined the users' perceptions toward e-government services in Scotland. The research stated that there are still many citizens who may not be able to engage with e-government services for various reasons. Some people may still not have access to an internet connection for a variety of reasons, including age, disability, limitations of digital skills, or lack of financial resources. In addition, citizens may be concerned about the safety and security of their personal data if they learn that the government collects and shares their personal information to improve the implementation of its services. As a result, citizens may be reluctant to engage with Government digital and mobile services as they may be wary of its privacy standards. Camilleri [7] developed a model from the modified UTAUT and TAM. An online survey is used to empirically examine the proposed research model. The participants of the survey were 706. Results revealed that the perceived usefulness and perceived ease of use had direct influence on the citixens intention to participate with the egovernment services. On the other hand, social influences and facilitating conditions had no significant impact.

One of the most popular theory that explains the information technology acceptance model is the Technology Acceptance Model (TAM) proposed by Davis [8] and the Unified Theory of Acceptance and Use of Technology (UTAUT) proposed by Venkatesh [3]. Based on literature and survey conducted in this study, it is believed that there are four factors that influence the Mataram citizens intention to use Mataramku Lapor. These factors are perceived usefulness, social influence, trust, and citizen awareness.

The first factor comes from the TAM proposed by Davis which is perceived usefulness [8]. Perceived usefulness is explained as the degree to which a person believes that using a particular technology will improve his or her job performance. Perceived usefulness has the perception that using the system, work can be finished quickly, helps save time and costs, and can increase work productivity [4]. Perceived usefulness factor is proven empirically, can explain end users' reasons for using information systems as well as explain that new systems that are being developed are accepted by end users [8]. Thompson [9] stated that people will use information technology if they understand the benefits of the technology.

Social influence factor is a factor that comes from UTAUT proposed by Venkatesh \& Davis [10]. According to Venkatesh [3] social influence is defined is defined as the extent to which an individual who is considered important by others believes that they must use a new system. Social influence influenced by attitudes, communication, and behavior mediated through technology [11]. Social influence presents an important role in depicting individual behavior in many contexts, including decision making, dissemination and adoption of a technology, and even social movements. Social influence can enter everyone, deliberately or unintentionally. It can be intentional, such as persuasion, which concerns how individuals influence others. It can also be unintentional, such as social examples, where individuals observe the behavior or habits of others which indirectly affect their behavior or habits [12].

Trust factor comes from the theory of Adoption of Egovernment proposed by Warkentin [13]. Trust is the belief that each party is interdependent and needs each other [14]. Simply put, system information describes technology as something that can be trusted. Technology can be trusted by an organization or individual depending on whether its acceptance or adoption affects the individual in his role in everyday life [15]. Trust is a central aspect in many transactions be it economic or information because of the deeply human need to understand the social environment, that is, to identify what, when, why, and how others behave [16]. Trust is an important factor at the initial stage of the 
introduction or adoption of online-based technology because trust is a factor that influences individuals to engage in online transactions and is an integral part of the system [5]. Lack of a Trust factor can prevent individuals from engaging in online transactions.

The last factor is Citizen Awareness. The Citizen Awareness factor is obtained from research by Mofleh [2] which shows that awareness of the existence of egovernment services is related to the use of e-government services. The same literature also finds that in the UK the lack of public awareness is a problem affecting the progress of e-government because people do not know that egovernment services already exist. It is concluded that the UK government is not making sufficient efforts in promoting e-government services which results in the underutilization of these services. In e-government context awareness means a knowledge or public awareness of egovernment in their country and the availability of online community services [2]. To implement e-government services, public awareness of the availability of the service itself is considered a significant success factor. The benefits that are expected from using e-government services, such as gains in efficiency, effectiveness, cost savings, and public value, cannot be realized if people do not use them. Research conducted in Indonesia by [17], concluded that the government needs to socialize or promote egovernment services to the citizens through all media. Socialization about how to use e-government applications is very important, because there are people who do not really understand the mechanisms / procedures related to egovernment applications. The socialization or promotion of e-government services is helpful for raising awareness about the role of citizens in a government to create a culture of participation.

\section{Methodology}

In this study, individual perspectives on the domains of this study will be explored, namely awareness, social influence, perceived usefulness, and trust in influencing people's interest in downloading or using the complaint handling applications. This study used a qualitative method with a phenomenological approach because this research aims to seek reality from individuals' narratives of their experiences and feelings, and to produce in-depth descriptions of the phenomenon. Qualitative with a phenomenological approach is an approach that studies the subjective experiences and perspectives of others from a phenomenon that has occurred or is felt. The steps in conducting qualitative research can be seen in Figure 1 below.

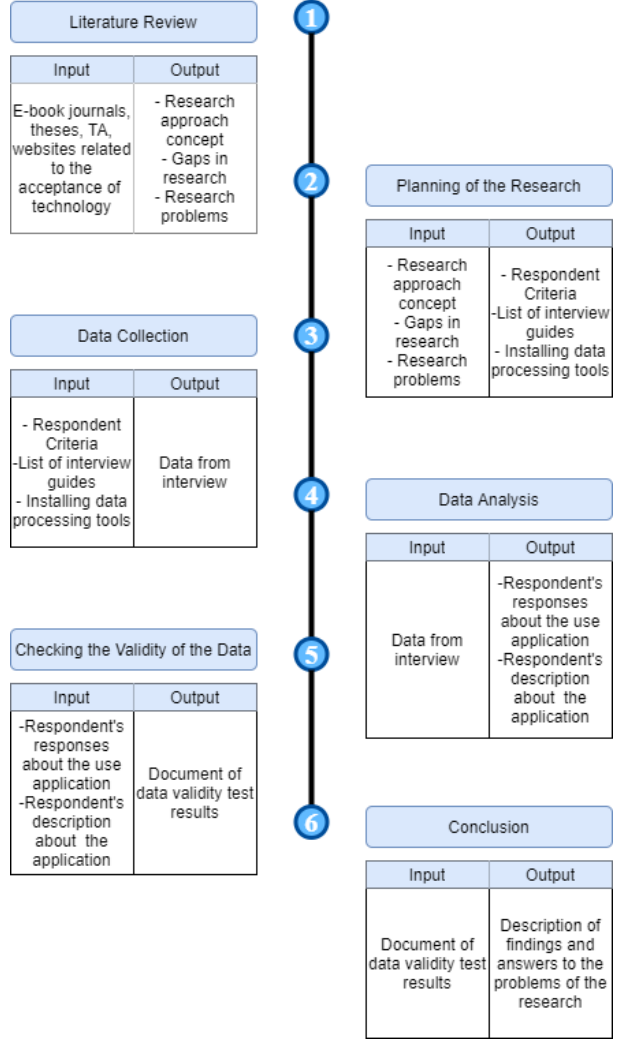

Fig. 1. The Research Stages

In this qualitative research phase, four domains were used, namely: citizen awareness, social influence, perceived usefulness, and trust. These four main domains will be tested to determine public interest in downloading or using the complaint handling application, so the researchers designed the initial conceptual framework of the study, as shown in Figure 2 below.

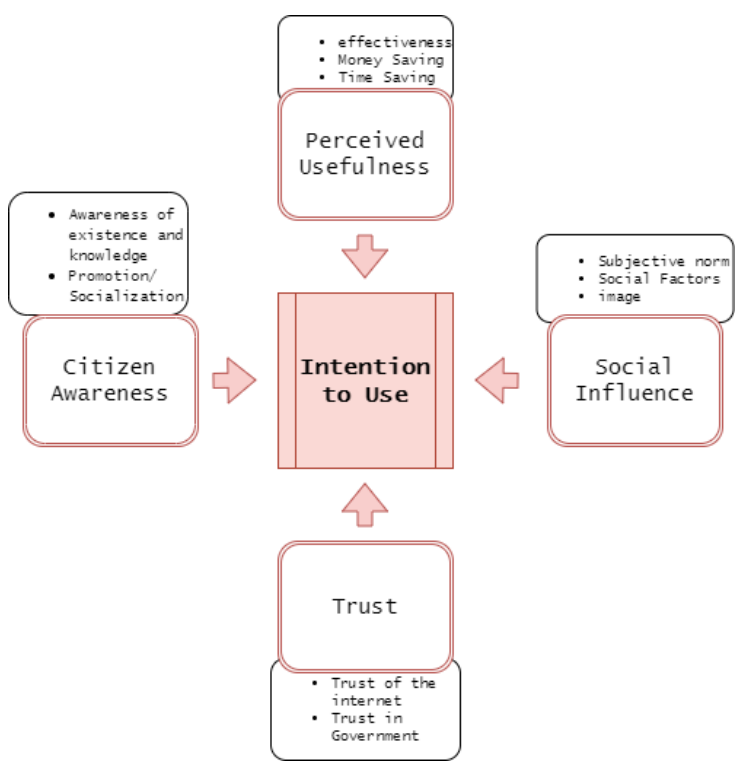

Fig. 2. Modified Research Model 
The data collection method used in this study is following the techniques proposed Cresswell [18], i.e: documentation, observation, and interviews with six research informants to identify and classify the data that has been obtained and analyze the confirmation of previous literature to see the pattern of phenomena based on the initial conceptual framework and the next step is to interpret the interview data to gather findings and recommendations from this study. In determining the criteria and categories of individuals to be selected as informants in this study, consideration, and selection of informant characteristics were carried out using purposive sampling, this technique is defined as a technique that selects research samples based on certain considerations and is able to represent the information needed. The sample must have sufficient knowledge and be able to explain the actual state of the object of research.

The interview period lasted one months (May to June 2020). Totally, six informants are divided into four informants representing citizen who already have experience using Mataramku Lapor and two informants representing Diskominfo (The Ministry of Communication and Information Technology) employees who have experience and knowledge in Mataramku Lapor development. Table I explains the mapping of the informant criteria used in this study.

\section{RESUlt AND DISCUSSION}

Throughout this paper, we have reviewed the theoretical foundations and research topics discussed in several literatures. In the following sections, we will provide the finding that influencing the intention to use Mataramku Lapor.

\section{A. Citizen awareness influencing the intention to use Mataramku Lapor}

Based on the results of observations, it shows that citizen awareness influences increasing user's intention to use the complaint handling application. All informants, specifically application users, have stated that they are aware of the existence of the application and the benefits offered by the complaint handling application. To implement e-government services, public awareness of the availability of the service itself is considered a significant success factor.

TABLE I. INFORMANT CRITERIA

\begin{tabular}{|c|c|c|c|c|}
\hline Informant Type & Age & Categories & Notes & Time of Interview \\
\hline $\begin{array}{l}\text { Informant } 1 \\
\text { (IN1.01) }\end{array}$ & 25 & $\begin{array}{l}\text { Mataramku } \\
\text { Lapor users }\end{array}$ & $\begin{array}{l}\text { The informant is a native of Mataram City who lives in the Udayana } \\
\text { area, Mataram City. Currently, the informant is working in the } \\
\text { marketing department at BRI finance. The informant admitted that he } \\
\text { had downloaded the Mataramku Lapor and had used it. The } \\
\text { informant has filed a complaint once. The informant's complaint was } \\
\text { related to the problem of illegal parking on public roads. }\end{array}$ & $\begin{array}{l}\text { 1st June } 2020 \\
\text { and } \\
15 \text { th June } 2020\end{array}$ \\
\hline $\begin{array}{l}\text { Informant } 2 \\
\text { (IN1.02) }\end{array}$ & 24 & $\begin{array}{l}\text { Mataramku } \\
\text { Lapor users }\end{array}$ & $\begin{array}{l}\text { The informant is a native of Mataram City who lives in the southern } \\
\text { Ampenan area, Mataram city. Currently, the informant is working as } \\
\text { a BUMN employee. The informant admitted that he had downloaded } \\
\text { the Mataramku Lapor and had used it. The informant has filed a } \\
\text { complaint once. The informant's complaint was related to the } \\
\text { problem of river overflow due to sedimentation. }\end{array}$ & $\begin{array}{l}\text { 5th June } 2020 \\
\text { and } \\
15 \text { th June } 2020\end{array}$ \\
\hline $\begin{array}{l}\text { Informant } 3 \\
\text { (IN1.03) }\end{array}$ & 26 & $\begin{array}{l}\text { Mataramku } \\
\text { Lapor users }\end{array}$ & $\begin{array}{l}\text { The informant is a native of Mataram City who lives in the Pagutan } \\
\text { area, Mataram City. Currently, the informant is working as an } \\
\text { employee at the Puri Indah Hotel, Mataram City. The informant } \\
\text { admitted that he had filed a complaint on the Mataramku Lapor } 3 \\
\text { times. Complaints aimed at the application also get an immediate } \\
\text { response. The informant's complaint was related to public order } \\
\text { issues, rainwater overflow, and the environment. }\end{array}$ & $\begin{array}{l}\text { 14th May } 2020 \\
\text { and } \\
\text { 1st June } 2020\end{array}$ \\
\hline $\begin{array}{l}\text { Informant } 4 \\
\text { (IN1.04) }\end{array}$ & 26 & $\begin{array}{l}\text { Mataramku } \\
\text { Lapor users }\end{array}$ & $\begin{array}{l}\text { The informant is a native of Mataram City who lives in the Lingkar } \\
\text { area. Currently, the informant works as a food entrepreneur. The } \\
\text { informant admitted that he had filed a complaint once on the } \\
\text { Mataramku Lapor. The informant's complaint was related to } \\
\text { environmental issues, namely illegal waste disposal. }\end{array}$ & $\begin{array}{l}\text { 6th June } 2020 \\
\text { and } \\
\text { 16th June } 2020\end{array}$ \\
\hline $\begin{array}{l}\text { Informant } 5 \\
\text { (IN2.01) }\end{array}$ & 27 & $\begin{array}{l}\text { Diskominfo } \\
\text { employees }\end{array}$ & $\begin{array}{l}\text { The informant is a Diskominfo employee at the PTIK division. Is a } \\
\text { native of the city of Mataram who lives in the Pagutan area. The } \\
\text { informant knew the conditions surrounding the Mataramku Lapor at } \\
\text { this time and the informant admitted that he had filed a complaint in } \\
\text { the application. }\end{array}$ & $\begin{array}{l}\text { 29th June } 2020 \\
\text { and } \\
\text { 30th June } 2020\end{array}$ \\
\hline $\begin{array}{l}\text { Informant } 6 \\
\text { (IN2.02) }\end{array}$ & 26 & $\begin{array}{l}\text { Diskominfo } \\
\text { employees }\end{array}$ & $\begin{array}{l}\text { The informant is a native of Mataram City who lives in the Kekalik } \\
\text { area. The informant also works as a Diskominfo employee in the } \\
\text { Encoding and Information Security division. Informants also both } \\
\text { know the current condition of the Mataramku Lapor. }\end{array}$ & $\begin{array}{l}\text { 11th June } 2020 \\
\text { and } \\
29 \text { th June } 2020\end{array}$ \\
\hline
\end{tabular}


The following are the results of the interview regarding the influence of citizen awareness on the use of the complaint handling application.

"Actually, I know this application from my friends who filing a complaint a lot via this application". (Informant 2)

"I found out about this application via social media that I have". (Informant 3)

"Its benefits make it easier for us to file a complaint to the authorities about problems that exist around the house, on public roads, or even in the public facilities". (Informant 4)

Keywords like "I know this application", "very useful", and "it's benefits" show that the complaint handling application users are aware of the existence of the application and its benefits. This is in accordance with the theory of Shareef [14] which states that when people are aware of the existence of a new system and already know the benefits offered by the system, people will tend to use the system.

"In my opinion, it really should be promoted and campaigned because people in Mataram must know this application because through this application we can help people". (Informant 2)

"In my opinion, the campaign or promotion is still lacking, because there are so many people who don't know this application, and in my opinion, it's still lacking to be promoted anyway". (Informant 4)

"I think the socialization of training program about this feature is good. To increase public knowledge about this feature, especially ordinary people who don't know". (Informant 4)

"I don't know of any training regarding this application features. But my advice is to immediately conduct training for the complaint handling application because this application is very helpful for the people". (Informant 1)

"I think it's also good to hold training for this application because there are so many ordinary people who don't know technology". (Informant 2)

Keywords from the interview results related to promotion or socialization of the complaint handling application such as "it really has to be promoted and campaigned because there are so many people who don't know", "the campaign or promotion is lacking", "the socialization training program about this feature is good to increase public knowledge", "it's also good to hold training in this application because there are so many ordinary people who don't know technology". The keyword of the sentence above confirms the function of promotion or socialization in increasing users of the complaint handling application is very important. By holding promotions or advertisements related to applications, more people will be aware of the existence and benefits offered by the application. In addition, holding training and socialization related to the features in the complaint handling application can also increase application users, considering that not all residents of Mataram City understand technology. This is supported by research conduct by Sadat [17] which concludes that the government needs to socialize or promote e-government services on an initiative to wider citizens through all media. The socialization or promotion of e-government services is useful for raising awareness about the role of citizens in a government to create an overall culture of participation.

To implement e-government services, public awareness of the availability of the service itself is considered a significant success factor. Usually, the community does not use a new system not because the system is bad, but the community itself does not know the existence of the system. The government can "force" public officers as well as citizens to switch to online services while at the same time improving the quality of their online services. Meanwhile, institutional leaders can show their support for the implementation of citizen-oriented e-government in various ways, such as making policy, both written and oral that can motivate, supervise and evaluate the implementation of these online services [19].

\section{B. Social influence influencing the intention to use Mataramku Lapor}

Social influence is one of the factors that significantly influence individuals to use e-government services. Social influence can go into every individual, intentionally or unintentionally. It can be intentional, such as persuasion, which concerns how individuals influence others [20]. In this case, social influence can take the form of an invitation or force from people around you, social factors, and the image of users who have used the application.

The following are the results of the interview regarding the influence of social influence on the use of the complaint handling application.

"I just heard from some of my friends that this application exists". (Informant 4)

"Yes, at least I am aware of the application, I know "oh apparently there is an application like this in my city". Furthermore, if I think this application is good, I will use it". (Informant 3)

"There was my own friend too, who recommended me “. (Informant 2)

"If our company or organization supports the complaint handling application, or maybe instructs us to use the application. So indirectly my friends and I will use the application ". (Informant 3 )

Some of the keywords forming the influence of social influence on the intention to use the application, such as "I just heard from some friends", "There was my own friend too, who recommended me". These sentences and words show that directly or indirectly application users can be influenced by their relatives or other people who influence them. In addition, keywords such as "our company or organization support the complaint handling application.... So, indirectly, my friends and I will use the application" as proof that the culture and environment can influence them in using the application. Social influence can go into every individual, intentionally or unintentionally. It can be intentional, such as persuasion, which concerns how individuals influence others [20]. 


\section{The image attribute has no effect on the desire of} potential users to use Mataramku Lapor

Using the application is believed to be able to increase the image of the application user. This can indirectly affect the user's desire to use the application. But based on the results of the interview, it is known that the image does not really affect the user's desire to use the application.

"It seems normal because I using this application cause its useful, not for showing off". (Informant 2)

"Nothing. It does not enhance the image either. But I feel proud using it". (Informant 3)

"Apparently no for this point." (Informant 4)

The answer from the informants regarding the image of application users is that they do not agree that using the application will improve their image in the community. Even the Informant 3 said that he felt that using the application does not boost his image in the community. This means that the image has no effect on the user's desire to use the application.

\section{Perceived usefulness influencing the intention to use Mataramku Lapor}

The following are the results of the interview regarding the influence of perceived usefulness on the use of the complaint handling application.

"I think filing a complaint using the complaint handling application is more effective and efficient than the manual way. Because by using the complaint handling application, when we encounter a problem around Mataram we can capture the image and then immediately complain it to the city government ". (Informant 3 )

"Very useful, because for example we are really lazy to take care of things like this, but we are not lazy because there is already an application ". (Informant 2)

"I think this application is in accordance with what is needed by the citizens, because it is very easy to use and easy to understand too ". (Informant 1)

"Yes, after I used the complaint handling application, I saved more time when it comes to filing a report ". (Informant 1)

"Of course, it is really saved time, because we can file a complaint anytime via this application. You don't have to leave the house or drive either. So, we can also file a complaint casually through this application. So, it really saved time ". (Informant 2)

"Yes, it doesn't take much time. The thing is, the application is very simple, so it doesn't take a lot of time ". (Informant 2)

"Using the complaint handling application can saves time in the process of filing a complaint, compared to the manual way processes which have many procedures. File a complaint manually has many procedures or steps which in my opinion are not very productive ". (Informant 3)

Several keywords were found, such as "more effective and efficient ", indicating that the informants agreed that using the complaint handling application to file a complaint was more effective than the manual way. In addition, they find this application very useful for them. Even users agree that the complaint handling application is in accordance with the reporting application required by the citizens. This is in accordance with a quote like the following; "Very useful, because for example, we are really lazy to take care of things like this, but we are not lazy because there is already an application", "I think this application is in accordance with what is needed by the citizen's". While the quote stating that the complaint handling application is very helpful in saving time and increasing productivity is as follows; "does not take much time, the thing is, the application is very simple", "using the complaint handling application I saved more time", "Of course it's really saved time, because we can file a complaints anytime via this application", "Using the complaint handling application can saves time in the process of filing a complaints, compared to the manual way processes".

Perceived usefulness refers to "how far a person believes that using certain technology will improve their job performance." [8]. Prospective users will usually use information technology if they understand the benefits or usefulness of the technology. Alambaigi [21] stated that perceived usefulness has been analyzed as an effective factor in increasing the level of acceptance of information technology.

\section{E. Trust influencing the intention to use Mataramku Lapor}

Trust itself is described as "a belief perception of the reliability and integrity of a system". Based on research [4] states that user trust and social influence are two significant factors that can influence an individual's desire to use an egovernment service. Trust becomes an important factor at the initial stage of the introduction or adoption of onlinebased technology because Trust is a factor that influences individuals to involved in online transactions and is an inherent part of the system [5].

The following are the results of the interview regarding the influence of trust on the use of the complaint handling application.

"I also believe the people behind the complaint handling application will not commit fraud or criminal acts using the accounts of their users ". (Informant 1)

"Believe in being able to convey messages that we have uploaded there for immediate follow-up ". (Informant 2)

"I believe that the government will solve the existing problems through this application ". (Informant 1)

"I believe the government can solve it, therefore I use this complaint handling application ". (Informant 2)

"I can trust only if the complaint I make, can be responded quickly by the officers ". (Informant 4)

The keywords like "believe that the government will solve the existing problems ", "I believe the government can solve it ". It is an expression of an informant who already has confidence in the complaint handling application. The informants use the complaint handling application because they give trust to the people who are responsible for the complaint handling application to be able to complete the complaints they have reported. In 
essence, public trust in technology or the government itself is very much needed for the success of information technology. One of the things that can build public trust in the complaint handling application is the responsiveness of the government in responding to citizen complaints. The fifth informant's quote said "if the citizen complaints is handled quickly and even can cut bureaucracy then the more they trust to the government. The citizen will be more able to trust the technology provided by the government ". Based on this sentence, the government will be able to gain public trust if they are responsive to handling citizen complaints. The slow response and follow-up to citizen complaints can be one of the reasons for the lack of complaint handling application users. This is reinforced by the informant's quotation as follows. "I can trust only if the complaint I make, can be responded quickly by the officers “.

\section{F. Maximum effort on promotion or socialization can increase awareness of Mataramku Lapor}

Promotion or socialization here is intended to create an introduction to the complaint handling application. Due to implementing e-government services, public knowledge, or awareness of service availability itself considered a significant success factor. The benefits that are expected from using e-government services, such as gains in efficiency, effectiveness, cost savings, and public value, cannot be realized if people do not use them. To increase public awareness, one way is to introduce this application through promotion or socialization. The following is the informant's statement regarding promotion or socialization of the complaint handling application.

"In my opinion, it really should be promoted and campaigned because people in Mataram must know this application because through this application we can help people”. (Informant 2)

"In my opinion, the campaign or promotion is still lacking, because there are so many people who don't know this application, and in my opinion, it's still lacking to be promoted anyway". (Informant 4)

"I think the socialization of training program about this feature is good. To increase public knowledge about this feature, especially ordinary people who don't know". (Informant 4)

"I don't know of any training regarding this application features. But my advice is to immediately conduct training for the complaint handling application because this application is very helpful for the people". (Informant 1)

Keywords such as should be promoted and campaigned, the campaign or promotion is still lacking, do not know of any training. It is an expression from informant who admits that the promotion or socialization of the complaint handling application is considered insufficient. In fact, if the Mataram City Government is serious and aggressive in terms of promotion or socialization, it can have a positive impact on public knowledge or awareness about the availability of e-government services, in this case, the complaint handling application. This is in line with research conducted by Sadat [17], which concluded that the government needs to socialize or promote e-government services in an initiative to wider citizens through all media. Socialization on how to use e-government applications is very important because there are people who do not really understand the mechanisms/procedures related to egovernment applications. The socialization or promotion of e-government services is useful for raising awareness about the role of citizens in a government to create an overall culture of participation.

\section{$G$. The role of influencers has an influence on raising awareness and attracting potential users to use the application}

Social influence is one of the factors that influences the interest of potential users to use the complaint handling application. It is believed that social influence can go into every individual, whether intentionally or not. It can be intentional, such as persuasion, which involves how individuals influence others. It can also be unintentional, such as social examples, where individuals observe the behavior or habits of others which indirectly affect their behavior or habits. One of the things that can be done to increase the social influence factor is by using influencer services. An influencer is defined as a person or group of people who capable to influence people's perceptions or preferences for a brand.

This finding is consistent with the statement of the Informant 5 who said that "in fact, it is because he is an influencer who is closer to the people and the people should be directly affected by the good impact". The Informant 5 also stated that "if necessary, it's the effective one, hiring influencers or celebrities, even though it's a bit odd for the government". The quote shows that the Informant 5 confirmed that using influencer services can increase public awareness because influencers are trusted to be closer to the public. This is in accordance with the theory [22] which states that influencers have more credibility and knowledge, where consumers state that they are willing to follow the recommendations of influencers.

\section{H. Raising the public understanding of usefulness of the application can increasing intention to use Mataramku Lapor}

Apart from public awareness and social influence, the level of understanding of the use of technology also influences on increasing the use of complaint handling applications. Based on the interview results, the application user said that the complaint handling application was in accordance with the citizen's complaint handling system needed by the public. Besides being able to increase work effectiveness, applications can also make users save their time by not spending too much time on unproductive things. The usefulness or benefits of the complaint handling application are pretty good. The problem is that people's understanding of the benefits or usefulness of the application itself is still lacking.

This was stated by Informant 5 which said that "in terms of application, it's actually pretty good for its business flow. Unfortunately, public awareness is still lacking. Even 
though this application exists, people do not want to use it.". In addition, Informant 6 also said that "this application is very useful because it makes it easier for the public in terms of filing a complaint. Applications have also been made according to public needs". The two quotes above say that the complaint handling application is pretty good, and easy to use, but even though it suits the public needs, this application is rarely used. Informant 2 said "it would be good to hold training in this application because there are so many common people who don't know technology". The statement above reveals the importance of public understanding of the usefulness or benefits of the application. By increasing public understanding of the usefulness or benefits of the application, it can raise the desire of potential users to use the application. Therefore, the perceived usefulness factor coupled with the public understanding of its usefulness is important to increase the use of the complaint handling applications.

\section{Quick response can build user trust to use the application repeatedly}

This finding was found on the trust factor when the researcher conducted interviews with informants. The third informant said "The government was able to complete every complaint reported by the citizen but perhaps the obstacle in terms of follow-up of each complaint might take a while. For example, my complaints used to be quickly responded by the government but recently my complaints seem ignored ". The quotation shows that the third informant has made complaints more than once because he has the experience that his complaints are responded quickly. The fourth informant also said "I can trust only if the complaint I make, can be responded quickly by the officers ". The informant stated that would have more belief in the government behind the complaint handling application if the complaints that were reported in the application received a quick response. This is reinforced by the article [23], where the article states that complaints that have not been conveyed or even ignored until the resolution is protracted, causing the public to become apathetic about public services and consider this condition as normal. If this happens the public will no longer trust the government, or the e-government services provided by the government. From this explanation, it can be concluded that the government's response in responding to complaints on the complaint handling application influences on the effectiveness of using the complaint handling application.

\section{$J$. The number of complaint handling application in a city and the government's commitment affect the use of the application itself}

This finding was obtained when the authors interviewed the second category of informants. The fifth informant's quote states "There are many "Lapor" applications in the city of Mataram such as lapor.go.id, MataramKu Lapor, and if I'm not mistaken there are still several other "Lapor" applications, the 112-call center. So, the Mataram citizens is confused, where should they filing a complaint, and which one is the most effective? ". This confirms that complaint handling service in Mataram City are not only one, but quite a lot. In the city of Mataram itself, the current channel used for complaint handling services is the MataramKu Lapor application, then there is Lapor.go.id, 112 call centers, and finally NTB Care. This leaves citizens confused as to where should they filing a complaint and which complaint handling services are most effective. In this case, the government should be more committed to strengthening the complaint handling application. Supposedly, the government only needs to focus on one application with the hope that the service by that one application is more optimal. That way the government can improve the quality of the complaint handling application service. The quality of service will increase the public's sense of trust in the government and the services provided by the government. Indirectly this influence on increasing the effectiveness of using the complaint handling application.

From the results of data interpretation, analysis, testing data, and information that has been obtained and formed into these findings, the final model of the research framework is produced, as in Figure 3 below:

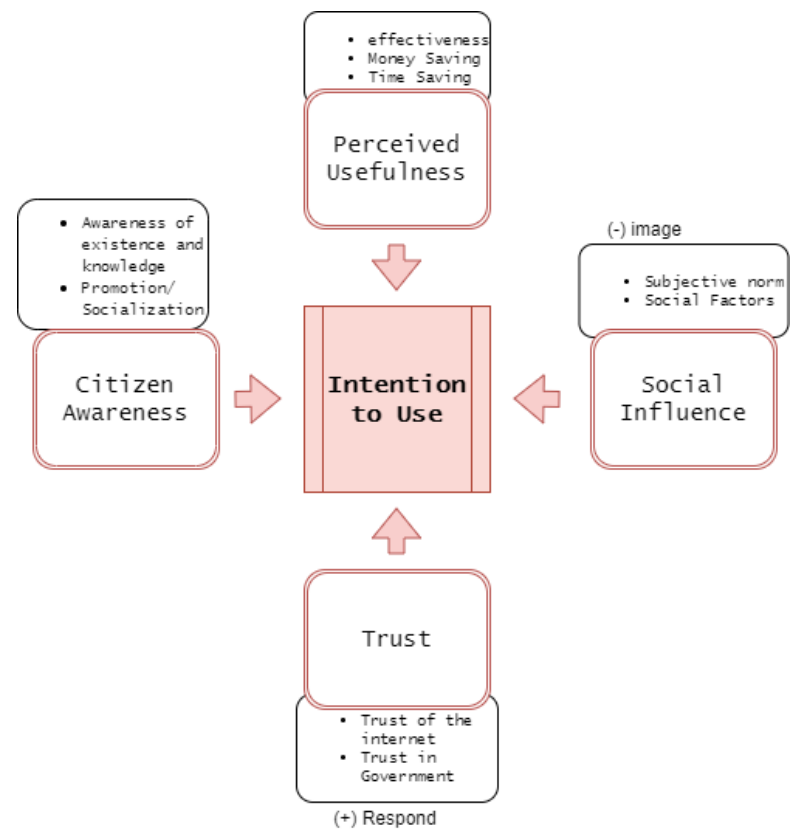

Fig. 3. The Final Model

From the results of data interpretation, analysis, testing data, and information that has been obtained and formed into these findings, the final model of the research framework is produced as in Figure 3 above. The development of the proposed model based on theory citizen awareness [14], social influence [4] [24] [3], perceived usefulness [8], [10] [25], and trust [25] [24] [26].

In previous research [3], social influence is known to have three elements, namely subjective norms, social factors, and image. Based on the new findings obtained by researchers, it is known that the image element does not significantly affect the desire of potential users to use the application. The image element in social influence 
has been removed because using e-government applications nowadays is considered normal and has no impact on increasing the user's image in society.

Previous research by [26] stated that trust only has two elements, namely trust in the internet and trust in the Government. But in this research the respond element is added based on new findings in the study. It is known that a fast response from the government can build people's trust in the application. This has the effect of increasing the number of application users.

\section{CONCLUSION}

Citizen awareness, social influence, perceived usefulness, and trust has been proven to increase the intention to use Mataramku Lapor. The level of user understanding of the usability of technology also influences on increasing application usage. Building user trust in the application and the government can also increase the effectiveness of using Mataramku Lapor. Each of these factors plays an important role in increasing the user's current state. Citizen awareness can be maximized by conducting socialization and promotion evenly to the citizen of the city of Mataram. Social influence is maximized by using influencers or millennials in promoting applications. Perceived usefulness can be improved by regularly updating and given the understanding of the Mataramku Lapor application to the citizen. Meanwhile, trust can be built by improving the service quality of Mataramku Lapor. To influence the effectiveness of usage and building public trust to use the Mataramku Lapor repeatedly, the government must ensure that the number of incoming complaints must be accompanied by a commitment to respond and handle complaints quickly and responsively. The results of this study provide an overview of user behavior and public perceptions regarding the intention to use Mataramku Lapor. Still, Further research is needed to confirm the possibility of a new model. There are some addition and reduction of variables outside the theory. Further research is needed to test the dominance of additional variables that arise against the research problem. There are limitations to this study. First, this study only takes one point of view from MataramKu Lapor, one of the citizen complaint handling system in Mataram city, Indonesia. The second is finding an informant who has file a complaint and the complaint has been responded by the government is consider difficult. The last is further research needs to be done to confirm each stage of the model that has been revealed through the qualitative methods in this study.

\section{REFERENCES}

[1] Mataram, "Google Play," [Online]. Available: https://play.google.com/store/apps/details?id=com.tb g.mataramkulapor\&hl=en_US. [Accessed 29 Maret 2019].

[2] S. Mofleh and M. Wanous, "Understanding Factors influencing Citizens Adoption of e-Government
Services in the Developing World: Jordan as a Case Study," Journal of Computer Science, vol. 7, no. 2, pp. 1-11, 2008.

[3] Venkatesh., M. G. Morris, G. B. Davis and F. D. Davis, "User acceptance of information technology: Towards a unified view," Management Information System Quaterly, vol. 27, pp. 425-478, 2003.

[4] T. D. Susanto and M. Aljozab, "Individual Acceptance of e-Government Services in a Developing Country: Dimensions of Perceived Usefulness and Perceived Ease of Use and the Importance of Trust and Social Influence," Procedia Computer Science, vol. 72, pp. 622-629, 2015.

[5] T. Haryanti and A. Subriadi, "Factors and Theories for E-Commerce Adoption: A Literature Review," International Journal of Electronic Commerce Studies, vol. 11, no. 2, pp. 87-106, 2020.

[6] G. G. Akbar, I. Kania, A. Ulumudin, G. Anggadwita, L. S. Harmanto and D. T. Alamanda, "Innovation in the Public Sector: The effectiveness of "LAPOR!" as one of the Smart City Programs in Bandung," Atlantis Press, pp. 297-302, 2018.

[7] M. Camilleri, "The online users' perceptions toward electronic government services," Journal of Information Communication and Ethics in Society, pp. 221-235, 2019.

[8] F. Davis, "Perceived Usefulness, Perceived Ease of Use, and User Acceptance of Information Technology," MIS Quarterly, vol. 13, no. 3, pp. 319340, 1989.

[9] R. Thompson, C. Higgins and J. Howell, "Personal computing: toward a conceptual model of utilization," MIS Quarterly, vol. 13, no. 3, pp. 125143, 1991.

[10] V. Venkatesh and F. D. Davis, "A Theoretical Extension of the Technology Acceptance Model: Four Longitudinal Field Studies," Management Science, vol. 46, no. 2, pp. 186-204, 2000.

[11] E. Bakshy, I. Rosenn, C. Marlow and L. Adamic, "The role of social networks in information diffusion," in Bakshy, Eytan \& Rosenn, Itamar \& Marlow, Cameron \& Adamic, Lada. (2012). The Role of Social $N$ Proceedings of the 21st Annual Conference on World Wide Web, 2012.

[12] R. B. Cialdini, Influence: Science and practice, 4th ed., Needham Heights: Allyn \& Bacon, 2001.

[13] M. Warkentin, D. Gefen, P. A. Pavlou and G. M. Rose, "Encouraging Citizen Adoption of eGovernment by Building Trust," Electronic Markets, vol. 12, no. 3, pp. 157-162, 2002.

[14] M. Shareef, V. Kumar, U. Kumar and Y. Dwivedi, "e-Government Adoption Model (GAM): Differing service maturity levels," Government information quarterly, vol. 28, no. 1, pp. 17-35, 2011. 
[15] S. Chandra, S. C. Srivastava and Y.-L. Theng, "Evaluating the Role of Trust in Consumer Adoption of Mobile Payment Systems: An Empirical Analysis," Communications of the Association for Information Systems, vol. 27, 2010.

[16] D. Gefen, E. Karahana and D. Straub, "Trust and TAM in Online Shopping: An Integrated Model," MIS Quarterly, vol. 27, no. 1, pp. 51-90, 2003.

[17] D. R. Sadat, M-government implementation evaluation in encouraging citizen participation in Indonesia: A case study of LAPOR, Manchester: School Of Environment, Education And Development, dissertation, Institute for Development Policy and Management, 2014.

[18] J. W. Cresswell, Research Design: Qualitative, Quantitative, and mixed methods approaches, California: SAGE Publications, 2014.

[19] A. Wulansari and A. P. Subriadi, "Developing Citizen Relationnship Management (CiRM) Oriented E-Government Maturity Model," IPTEK Journal of Engineering, pp. 22-28, 2017.

[20] J. P. Dillard and M. W. Pfau, The Persuasion Handbook: Developments in Theory and Practice, 1st ed., Thousand Oaks: Sage Publications, 2002.

[21] A. Alambaigi and I. Ahangari, "Technologyåß Acceptance Model (TAM) As a Predictor Model for
Explaining," International Journal of Agricultural Management and Development, vol. 6, no. 2, pp. 235247, 2015.

[22] A. Chopra, V. Avhad and S. Jaju, "Influencer Marketing: An Exploratory Study to Identify Antecedents of Consumer Behavior of Millennial," Business Perspectives and Research, pp. 1-15, 2020.

[23] A. S. Apriyanto, "OMBUDSMAN RI," 2020. [Online]. Available: https://ombudsman.go.id/artikel/r/artikel-tingkatkan-pelayanan-publik-melalui-penangananpengaduan . [Accessed 15 Juni 2020].

[24] R. Kumar, A. Sachan, A. Mukherjee and R. Kumar, "Factors influencing e-government adoption in India: a qualitative approach," Digital Policy, Regulation and Governance, 2018.

[25] O. A. Hujran, A. Aloudat and I. Altarawneh, "Factors Influencing Citizen Adoption of E-Government in Developing Countries: The Case of Jordan," International Journal of Technology and Human Interaction, vol. 9, pp. 1-19, 2013.

[26] F. Belanger and L. Carter, "Trust and risk in egovernment adoption," Journal of Strategic Information Systems, vol. 17, pp. 165-176, 2008. 